Annales Missiologici Posnanienses t. 25 (2020), s. 147-185

doi: 10.14746/amp.2020.25.10

ORCID: 0000-0001-7921-1051

THIERRY MEYNARD

Sun Yat-sen University

\title{
For the record: The Canton exile of the missionaries (1666-1671) by the Polish Jesuit Szpot Dunin
}

\author{
Translation and transcription from the Latin by Robert Danieluk, ARSI, \\ revised by Daniel Canaris, Sun Yat-sen University
}

\section{Introduction}

After charges were brought against the German Jesuit Adam Schall von Bell (1591-1666) working at the court, most of the missionaries in China were sent to Canton. During the five years of the Canton exile (1666-1671), the China Jesuit mission suffered its worst crisis since its inception by Michele Ruggieri (1543-1607) and Matteo Ricci (1552-1610) eighty years before. Not only the missionaries were secluded in the Jesuit house of Canton and cut off from their communities, but also the Chinese Rites Controversy erupted again and divided the missionaries on the issue whether the Chinese Catholics were allowed to perform the traditional rites towards Confucius and their own ancestors. The Jesuit Prospero Intorcetta (1626-1696) and the Dominican Domingo Navarrete (1610-1689) went to Rome to present arguments for or against the toleration of the Chinese Rites among Chinese Christian converts. But the Jesuits, who supported the Rites, lost their case: in 1700, the Sorbonne University decided against the Rites, and the pope Clement XI (r. 1700-1721) condemned them and forbade further discussion on them with the decree Cum Deus optimus, signed in 1704, but issued only in 1710 .

Based on resources in the Jesuit central archives in Rome, the Polish Jesuit Tomasz Ignacy Szpot Dunin (1644-1713) had already worked in the years 1690-1700 in compiling an history of the China mission (Historia Sinarum), and apparently because of his expertise on the China mission, the Superior 
General Michelangelo Tamburini (r. 1706-1730) commissioned him, some time before the papal decree was issued in 1710, to write the history of the China mission. As Robert Danieluk, S.J., has shown, Szpot spent the last twenty-four years of his life in Rome (1689-1713) hearing confessions at Saint Peter's Basilica, and in 1710 finished his monumental work on the history of the China mission between 1640 and $1700 .{ }^{1}$ Szpot deeply believed that the recent judgements against the Jesuits' missionary practices were a "tragedy" and sought to interpret the historical documents in a way that could justify the Jesuit China mission. The resulting work of his labours, the Compilation of Chinese History (Collectanea historiae sinensis; ARSI, Jap. Sin. 104-105), with a first volume (tomus I) concerning the history from 1641 to 1664, and the second volume (tomus II) from 1664 to 1700. This second volume itself consists of five parts: the first part describes the development of Christianity under the Qing dynasty and the sudden persecution under Kangxi's regency (1644-1667); the second part describes the re-establishment of the Jesuits and their astronomy at the court (1668-1671); the third (1671-1680), fourth (1681-1692) and fifth parts (1692-1700) describe the development of Christianity.

The overall narrative depicts a flourishing mission which has successfully overcome the crisis of the political persecution (1665-1667) and won the trust of the Kangxi emperor. It is striking that Szpot's account barely mentions the disputes concerning the Chinese Rites among the missionaries in China, that is, whether the Chinese Catholic are allowed or not to perform the traditional rites towards their ancestors and Confucius. He does briefly allude to the arrival in China of the Paris Foreign Mission, but he seems to be silent about the interdiction of the Chinese rites in 1693 by the Apostolic Vicar Charles Maigrot (1652-1730) ${ }^{2}$. The Chinese Rites Controversy is only discussed in the second part, Chapter 5, which is titled "The Activities of the Fathers Exiled in Canton." We present here a brief analysis of this important chapter, followed by the English translation of the text and its Latin transcription, by Robert Danieluk, revised by Daniel Canaris. ${ }^{1}$

\section{Defending the Chinese rites}

Szpot presents the Chinese Rites Controversy as a conflict between the Jesuits and the Dominican Navarrete. The opposition of Spanish Franciscan Antonio Santa Maria de Caballero (1602-1669) is not mentioned, and the report

\footnotetext{
${ }^{1}$ See Robert Danieluk, "Konfesjonał i pióro: Tomasz Ignacy Szpot Dunin, polski historiograf jezuickiej misji w Chinach," in Iesuitae in Polonia - Poloni Iesuitae. Piśmiennictwo łacińskie czasów nowożytnych, ed. Jarosław Nowaszczuk. Szczecin: Volumina, 2017, pp. 75-108.
} 
of the Italian Jesuit Niccolò Longobardo (1565-1655), reappearing "from ashes" in Canton forty years after its composition, is only mentioned in passing without explaining its content, that is, Longobardo's opposition to using the Chinese term Shangdi, or the Lord-on-High, found in the ancient Chinese classics, as an equivalent for God. The ambivalence of some Jesuits like Jean Valat (1614-1696) towards the Chinese rites is not mentioned. Szpot also omits the opposition of another French Jesuit, Adrien Grelon (1618-1696), to baptising Chinese fasters and allowing hats during Mass. ${ }^{2}$

Szpot seeks to showcase the Jesuits' restraint in the Controversy. Indeed, he mentions that after Navarrete had declared his opposition to the Chinese rites, the Jesuits in Canton "were obliged to compose treatises" from 1666 to 1670, and to send them to Europe. As he explains, the Jesuits in Canton were hoping that Navarrete who had suffered with them in China will promote peace and unity in Europe, but they felt deceived when in 1676 Navarrete published at Madrid his Tratados, in which he denied that ancient Chinese had any knowledge of God and attacked the Jesuit missionary policy and Chinese culture itself. As Szpot says, "the contents of [Navarrete's] book seemed believable, or at least diminished or put in doubt the beliefs about China which until recently were considered indisputable." Therefore, it is only when the Jesuits in China knew about the Tratados that they wrote in 1680 a new round of treatises to refute Navarrete's attacks. ${ }^{3}$

Szpot provides a very precise documentation of the refutations to $\mathrm{Na}$ varrete's work, in defense of the Chinese Rites, that were written during the Canton exile between 1667-1670, and in 1680. Concerning the first period, 1667-1670, Szpot lists three texts by the Dominican Domenico Sarpetri (1623-1683), followed by the works of three Jesuits, Intorcetta, Francesco Brancati (1607-1671) and Jacques Le Faure (1613-1675). In 1680, four other Jesuits, Giandomenico Gabiani (1623-1694), Lodovico Buglio (1606-1682), Ferdinand Verbiest (1623-1688), and Francesco Saverio Filippucci (1632-1692), wrote treatises, and even the Chinese Dominican Gregorius Lopez (Luo Wenzao, 1617-1691), ordained bishop in 1685, supported the Jesuits in his Chinese writtings.

As just said, Szpot considered Navarrete's Tratados a very influential work which convinced many people and cast doubt on the Jesuit stance. From read-

${ }^{2}$ At the request of the Superior General, Szpot added elements about the "persecution that the Jesuits endured from the French apostolic vicars"; see letter of Szpot to Tamburini, dated 23 January 1710; ARSI, Jap. Sin. 173, f. 22 ${ }^{\text {rv }}$. Szpot's addition about the Chinese Rites and the issue of jurisdiction of the Apostolic Vicars, can be seen in his revised version of Pars V, where he added the Caput III: De dissensionibus ab anno 1690. ad annum 1696. inter PP. Lusitanos et Gallos; Jap.Sin.111: ff. 73 $-99^{\mathrm{v}}$.

${ }^{3}$ Szpot revised partially the Collectanea, and we consulted the revised version of chapter V of part 2, which is almost verbatim the copy of the first version; see ARSI Jap.Sin.109: 124-139. 
ing Szpot's account, one question arises: why did the many treatises written by the Jesuits against Navarrete fail to convince? Szpot himself does not give a direct answer, but from his chronology of the documents we can find a clue to the answer.

When Intorcetta was in Europe in 1670-1672, he arranged the publication of four works written in Canton which he had brought over to Europe: Grelon's Histoire de la Chine (Paris, 1671), François Rougemont (1624-1676)'s Relaçam do estado politico e espiritual (Lisbon, 1671; published also in Latin as Historia Tartaro-sinica nova, Lisbon, 1672), Intorcetta's Compendiosa narratione (Rome, 1672), and Gabiani's Incrementa Sinica ecclesice (Wien, 1673). All these works narrate the persecution of the Church during the Qing dynasty and report the arrest of Adam Schall at the court and his near martyrdom, but they do not deal with the Chinese Rites controversy as such.

In fact, none of the defenses in favor of the Chinese Rites written in Canton in 1667-1670 were published when Intorcetta brought them to Rome in 1672. Instead, Intorcetta handed them over to Giovanni Paolo Oliva (r. 1664-1681), the Superior General of the Jesuits, to be used by Progaganda Fide, the Holy Office, and other cardinals. The Jesuits' restraint in not publishing their refutations of Navarrete's works reflects their desire not to escalate the controversy. As Szpot suggests, the Jesuits were hoping that Navarrete would not bring the case of the Chinese Rites to Rome, and that he would not publish anything against them.

It seems, however, that the Jesuits miscalculated Navarrete's intentions and were taken by surprise when the Tratados was published. The Jesuits did manage to stop the publication of Navarrete's Controversias in 1679, an even more damaging work for the Jesuits' reputation, but their own polemical treatises written in Canton still remained unpublished. In 1687, Philippe Couplet (1623-1692) published the monumental Confucius Sinarum philosophus, which primarily comprised translations of the Confucian Classics and an introduction justifying Ricci's missionary policy of adopting ancient Confucianism. Yet the work can only be considered as an indirect refutation of Navarrete, who is not mentioned even once. ${ }^{4}$ With Maigrot's interdiction of the Chinese Rites in 1693, the Controversy entered into a critical stage. Both sides published prolifically new and old works: in 1700 the works by the Do-

${ }^{4}$ Concerning the controversy on the fasters, the issue is about whether Chinese vegetarians should be admitted or not to baptism, unless they first eat some meat; in China, vegetarianism was closely associated to Buddhism; see Thierry Meynard, "Could Chinese vegetarians be baptized? The Canton Conference and Adrien Grelon's report of 1688," Archivum Historicum Societatis Iesu (AHSI) vol.87, fasc. 173 (2018-I): 75-145. Concerning the controversy on the hat, the issued was whether the priests and Chinese catholics should be allowed to wear a hat during mass. In China, having a hat is a mark of respect. 
minican Sarpetri and the Jesuits Intorcetta, Brancati and Le Faure, were finally published some thirty years after their composition in Canton. Most of them were published by Nicolas Pépie in Paris, thus indicating that there was a move from the Jesuit Superior General Tirso González (1686-1705) to influence the theological commission of the Sorbonne which was about to examine the issue of the Chinese Rites.

This suggests that, despite the very influential Confucius Sinarum philosophus, the important sinological work on the Chinese Rites which Sarpetri and the Jesuits conducted in Canton between the years 1666-1670 reached the European intellectual scene too late to turn things around. This was especially true in France where the anti-Jesuit currents fed by the Jansenits and the Paris Foreign Mission combined to result in the condemnation of the Chinese Rites by the Sorbonne.

\section{Promoting Chinese clergy and liturgy}

The second half of the chapter concerns the admission of the Chinese to the priesthood and the related issue of the liturgy in Chinese language. The Canton exile had made the missionaries aware of the weakness of a church that was exclusively dependent on foreigners. At that time, there was indeed only one Chinese Jesuit priest. Szpot mentions as his main source two unknown letters by Rougemont of 1671. An earlier letter (1667) of Rougemont on this topic is well known. ${ }^{5}$ Five reasons are listed in favor of Chinese priests. First, distance makes it difficult to bring foreign priests over to China. The second and third reasons concern cultural and political identity: Chinese priests are more easily accepted than foreigners. The fourth is that the social standing of the Jesuit missionaries depend on their work in the astronomical bureau, which is very unstable as the persecution against Adam Schall shows. The fifth reason is that other missions have sucessfully promoted indigenous people to priesthood, and that the Chinese Church does not lack suitable candidates. In comparison with the letter of 1667, the cultural argument is new: with the end of the persecution in 1671 and the quick return of the missionaries to their mission

${ }^{5}$ In his interpretation, Szpot may have been influenced by Couplet's report mentioned three times in the chapter: Philippe Couplet, Breve relatione dello stato e qualità delle missione della Cina, dedicata agl'Em. et Rm. Signori Cardinali di Propaganda, 1688; ARSI Jap.Sin.131. It was translated by Couplet himself into Latin: Relatio de statu et qualitate missionis Sinicæ post reditum Patrum e Cantoniensi exilio sub annum 1671. The Italian version was published in: Secondino Gatta, Il natural lume de Cinesi: Teoria e prassi dell'evangelizzazione in Cine nella "Breve relatione" di Philippe Couplet S.J. (1623-1693), Monumenta Serica Monograph Series XXXVII. Nettetal: Steyler Verlag, 1998. 
field, Rougemont wants to stress that the locals still have a cultural advantage in transmitting the Christian faith. Also, despite the change of political circumstances in Beijing after Verbiest won over the trust of Kangxi and restored the European astronomy, Rougemont wants to stress the unstable position of foreigners working at the court, and thus the need to develop Chinese clergy.

The main objection raised is that even if Latin training were to be offered to seminarians in Macau it would be difficult for local priests to say Mass in Latin, as the experience of the Paris Foreign Mission in South Asia has shown. Therefore, the logical solution is to allow Mass to be said in Chinese language. ${ }^{6}$ It is recalled that similar allowances are given to the Maronites, Armenians, Ethiopians and Slavs, and that pope Paul V (r. 1605-1621) had already given permission for a vernacular liturgy in China, but this was not implemented at that time. So far, it was argued that the Chinese to be ordained priests would not have to learn Latin, but could say Mass in Chinese, but here the argumentation becomes rather extreme, stating that Chinese should not study Latin at all! In fact, it would be dangerous to introduce the Latin language into China, firstly because the Chinese authorities would be suspicious of a language they cannot understand, and secondly because the Chinese who know Latin could access heretical books from Europe which might compromise the purity of faith and, as a window into European disorder, be cause of scandal. An interesting point is made about the choice of candidates to priesthood: young people are not suitable because they are too fickle, but older people, whose solid faith and zeal were proven by the vicissitudes, would be better suited. Thus, the rather original solution proposed is to ordain Christian widowers, among whom the Jesuits are quite optimistic about finding suitable candidates.

In his letter of 1667, Rougemont had already made similar points, which he repeats in his two letters of 1671. Besides Rougemont's two letters, Szpot consulted also Couplet's Breve relatione dello stato e qualità delle missione della Cina, as he indicates in a marginal note of the revised version. However, Szpot does not seem convinced by this interdiction of learning Latin in China, which he sees as motivated by "European interests."

\section{Conclusion}

The account by Szpot has an important documentary value in that it cites texts and letters which are otherwise unknown to us, like the two letters on

\footnotetext{
${ }^{6}$ See Thierry Meynard, The Jesuit Reading of Confucianism: The First Complete translation of the Lunyu (1687) published in the West. Boston: Brill, 2011; Thierry Meynard, The Confucius Sinarum Philosophus: The First Translation of the Confucian Classics. Rome: IHSI, 2010.
} 
the Chinese clergy and liturgy by Rougemont of 1671. A complete investigation of the different accounts by Szpot in the future may allow us to discover documents which have been lost or are unknown to us. Those new documents will complete further our knowledge of the history of Qing dynasty, which has recently received a new impetus with the rediscovery of Manchu and Western sources.

Clearly Szpot is not neutral. He attempts to demonstrate the poor knowledge of China held by the Dominican Domingo Navarrete and by the French Apostolic Vicar Pierre Lambert de la Motte and the error of former's opposition to the Chinese Rites and to the latter's resistance to a Chinese clergy and liturgy. But when he writes his Collectanea in 1710, he is fully aware that this cause had already been lost after the papal decree of 1704 .

The Collectanea by Szpot presents an abundant source of information on the China Jesuit mission in the seventeenth century and is also useful for understanding the history of China in the early Qing dynasty. We hope that the full Latin text of the Collectanea may be published one day and, possibly, translated into the vernacular.

\title{
Tomasz Ignacy SzPot Dunin, "Compilation of the Chinese history"
} Book 2, Part 2, Chapter 5: The Activities of the Fathers Exiled in Canton ${ }^{7}$ ARSI, Jap.Sin.104, f. $233^{\mathrm{v}}-239^{\mathrm{v}}$

\author{
Translation by Robert Danieluk, ARSI, \\ Annotation by Thierry Meynard, Sun Yat-sen University, \\ Revised by Daniel Canaris, Sun Yat-sen University
}

\section{I.}

While the Beijing Jesuits were preoccupied with the complete restoration of Christianity [in China], the missionaries exiled in Canton, after consulting with the Beijing Jesuits by letter, sought to determine how such a vast empire ought to be converted and how Christianity could be preserved if it were threatened by this persecution. In the first part we have examined the reso-

\footnotetext{
${ }^{7}$ Rougemont, Letter, Canton, 1667; Rome, BVE, Fondo Gesuitico 1257/29; partially published in Joseph Bertrand, Mémoires historiques sur les missions des ordres religieux. Paris: Brunet, 1862, pp. 396-398; entirely published in Henri Bosmans, "Documents relatifs à la liturgie chinoise: le mémoire de François de Rougemont à Jean Paul Oliva," Acta Bollandiana 33 (1914): 273-293. Besides documents by Rougemont, we have also documents by Intorcetta, Gabiani et Couplet in support of the Chinese liturgy; Intorcetta, Informazione, 24 March 1672, APF - SRC I (1623-1674), ff. 573-582; copy BVE Fondo Gesuitico 1257/14; in Italian; published in original Italian in François Bontinck, La lutte autour de la liturgie chinoise aux XVIIe et XVIIIe siècles. Louvain: Nauwelaerts, 1962, pp. 437-460.
} 
lutions of the Fathers' famous meeting held in jail. ${ }^{8}$ After deliberations over many sessions, all the Fathers reached unanimous agreement that the missionaries should follow the same practice in the administration of the sacraments, in preaching God's law and in observing some Chinese rites. The fact that all these decisions were based on papal bulls, decrees of the Sacred Congregation for the Propagation of the Faith, and declarations of the Holy Inquisition that were sanctioned by Pope Alexander VII would seem to remove all differences of opinion, which is enemy of the charity required by the apostolic office. ${ }^{9}$ If only those who had come later to preach the Gospel in China had accepted these resolutions with the same spirit as the older missionaries! These resolutions were examined with so many years of experience and were approved and confirmed by all the Fathers from three religious orders who gathered at that meeting. ${ }^{10}$ (See Father Philippe Couplet's Report to the Sacred Congregation). ${ }^{11}$

\section{Controversies among China missionaries about the Chinese rites}

Yet the ignorance of the things of this empire and the belief that Chinese customs are comparable to those of the Americans or other Indian peoples misled them so much that they disapproved many things, prejudiciously and wrongly maligning the Society of Jesus, which had worked in China for almost a century, with the claim that it had turned a blind eye to Chinese superstitions and not preached Christ Crucified. Without a doubt, their minds were confounded by Confucius, while the rituals for deceased ancestors had for them appearance of impiety. ${ }^{12}$ Likewise, they considered as erroneous some other practices regarding the administration of sacraments accommodated to the delicate habits and effeminate modesty of the Chinese. ${ }^{13}$

${ }^{8}$ As Henri Bosmans remarks, "the aim was to have a Chinese clergy, and the Chinese liturgy was only a way to facilitate this indispensable recruitment." Bosmans, "Documents relatifs à la liturgie chinoise: le mémoire de François de Rougemont à Jean Paul Oliva," p. 277.

${ }^{9}$ The 42 points of the Canton conference (18 December 1667- 26 January 168) are listed before; see Pars I, caput VI, De restituta Civitati Macao libertate, Patrum in Exilio existentium circa Ecclesiam Sinicam Statutis, \& Christianae Religionis in Sinis statu, 195r-197v. For an English translation of the 42 points, see: Ip Ka Kei, The Canton Conference (1667-1668): its content and significance; Master thesis. Macao: Saint Joseph University, 2010.

${ }^{10}$ In fact, Antonio Santa Maria de Caballero refused to sign the resolutions of the Canton conference, and Domingo Navarrete later retracted his signature.

${ }^{11}$ Philippe Couplet, Breve relatione dello stato e qualità delle missione della Cina; ARSI Jap. Sin. 131.

${ }^{12}$ This concerns the point 41 about the rituals to Confucius and the ancestors.

${ }^{13}$ This concerns the points 3-4-5 about the baptism of adult women without direct physical contact with the priest. 


\section{Jesuit missionaries slandered by some in Europe}

These calumnies had already spread in the past years through this empire [of China], from where they entered the nearby Indies and penetrated Europe. Finally, they turned to Rome, addressing those ears that are fastidious in preserving the purity of the Holy Faith. They would almost always be heard by people who were not competent in Chinese matters with the result that the domestic peace of the missionaries in China was disturbed. Hence, those exiled in Canton, who were highly qualified by their writings, experience, zeal, holiness of life and work for Christ in China, were obliged to compose some treatises in order to inform all, but especially the Sacred Congregation for the Propagation of the Faith and the Apostolic See, about the Chinese rites and some other controversies raised among the missionaries.

\section{Exiled Fathers in Canton write apologies in self-defense}

At the beginning, the Reverend Father Friar Domenico Maria Sarpetri, or of Saint Peter, a member of the Dominican order and lecturer in theology, wrote in 1668 a treatise, in which he refuted the book by Niccolò Longobardo, which had been resurrected from ashes, and defended the practice of the Fathers of the Society of Jesus in relation to what terms should be used in China to speak about God, angels and soul. ${ }^{14}$ To this he added an authentic testimony by which he confirmed the practice of our Fathers concerning the conversion of China to the faith. ${ }^{15}$ Finally, in 1670 the same author produced another trea-

${ }^{14}$ Domenico Maria Sarpetri was the one responsible for bringing the point 41 about the rituals to Confucius and the ancestors during the conference. He wrote in Canton a manuscript in Spanish, addressed to Intorcetta and dated 20 July 1668, certified as original copy by Pacheco and Ferrariis: Tratado del R.P.F. Domingos Sarpetri sobre la sentencia del P. Longobardi em materias sinicas; ARSI: Fondo Gesuitico I.2: ff. 1-24; two other manuscript copies in ARSI: Fondo Gesuitico I.2. Another copy is BNF Espagnol 409: 106-115, certified by Couplet. The printed version: De Sinensium ritibus politicis Acta, seu Appendix ad scripta R.P. Sarpetri Theologi ex Sancti Dominici Ordine, Missionarii Sinensis, De Deo Uno, Vivo ac Vero, A Veteribus Sinis per Duo Annorum Milla cognito, adversus scripta P. Longobardi S.J. Paris: Nicolas Pépie, 1700. This refutation is also mentioned with another Latin title as: Tractatus... ad lectionem Sacrae Theologiae Panormi approbati, quo refutat tractatum P. Longobardi e cineribus redivivum \& defendet praxim Societatis in usu nominum, quibus Deus, Angeli, anima, etc, Canton, 1668; see Acta cantoniensia, pp. 70-71.

15 This may refer to Testimonium de libro sinico P. Matthaei Riccii qui inscribitur Tien-chu Xe-y [Coelorum Domini vera ratio], dated 9 May 1667, Canton; published in Apologia pro decreto, Louvain, 1700, pp. 1-2; or Testimonium de praxi missionariorum Sinensium è Societate Jesu, circa Confucium et progenitores defunctos, 4 August 1668, Canton; published in Défense des nouveaux Chrestiens et des Missionaires de la Chine, du Japon, et des Indes contre deux livres intitulez La Morale pratique des Jésuites, et l'esprit de M. Arnauld I (Paris 1688), pp. 225-232; and in Apologia pro decreto (Louvain, 1700), pp. 3-7. 
tise to which he gave the following title "Brief notice about some of the reasons for which Chinese Christians should be allowed to practice the cult of Confucius and the deceased, just as it was permitted by the Holy Inquisition at the time of Alexander VII." 16

Similarly, in 1668, Father Prospero Intorcetta of the Society of Jesus wrote the "Apologetic defense of the duties and civic rituals with which the Chinese commemorate Confucius and deceased ancestors." $"$ He was followed by the Jesuit Francesco Brancati, missionary in China for 35 years, who prepared in 1669 the "Response to the doubts concerning the Chinese rites," to which he added the Chinese texts. ${ }^{18}$ The same year, Father Jacques Le Faure of the same Society, former professor of what is called "scholastic theology", produced at Poitiers the "A theological and historical dissertation about the ancestral piety of the Chinese towards their deceased ancestors and special observances towards their teacher Confucius," with an appendix and an epilogue. ${ }^{19}$

\section{Confucius translated into Latin by our Fathers}

Eventually, in order to know from his own books who Confucius was and what his teaching was, which was so highly venerated among Chinese lite-

${ }^{16}$ Sarpetri, Breve notitia de unos de los fundamentos, que hay para permitir a los Cristianos Chinos el culto de Confucio y de los difunctos, ms. dated 30 September 1670 Ajuda 49-IV-62: 697$713 v$; Latin version: Brevis explicatio rationum aliquarum, propter quas Christianis Sinensibus liber relinquitur usus caeremoniarum, quibus Confucius et progenitores suos venerantur, quemadmodum permisit Sacra Congregatio Inquisitionis Universalis sub Alexandro VII, Canton, 31 October 1670, published in Apologia pro decreto S.D.N. Alexandri VII et praxi Jesuitarum circa caerimonias, quibus Sinae Confucium \& progenitores mortuos colunt, ex patrum Dominicarum \& Franciscanorum scriptis concinnata. Louvain: 1700, pp. 21-68.

${ }^{17}$ Prospero Intorcetta, Apologetica disputatio de Officiis et Ritibus, quibus Sinenses memoriam recolunt Confucii Magistri, et progenitorum suorum, BVE Fondo Gesuitico 1249/10, ff. 639-690; ms. BNF 409: 193-209, 214-242. It was written in response to Navarrete's Declamatio, and approved on 15 August 1668 by Pacheco after 6 other Jesuits had read it; published as: Testimonium de Cultu Sinensi, 1668. Paris: Pépie, 1700.

${ }^{18}$ Francesco Brancati, Responsio apologetica de Sinensium ritibus politicis, ad R. P. Dominicum Navarete, ordinis Praedicatorum, completed on 4 September 1669. Manuscripts: Rome, BVE, Fondo Gesuitico 1250/5, 1251/8, 1299 and 1498; BNF Bréquigny 20:1-153; Ajuda 49-IV-62.1633 \& 49-VI-8.9337. The work was published as: De Sinensium ritibus politicis acta. seu R. P. Francisci Brancati, Societatis Jesu, apud Sinas per annos 34. Missionarii, responsio apologetica ad R. P. Dominicum Navarette ordinis praedicatorum. Paris: Nicolas Pépie, 1700.

${ }^{19}$ Jacques Le Faure, Dissertatio theologico-historica de avita Sinorum pietate erga defunctos et eximia erga Confusium magistrum suum observantia, Prolegomena ad R.P. Fr. Dominicum Navarette, 1669; BNF Bréquigny ms 19; BVE Fondo Gesuitico 1250/3; Vanves, Brotier 104, 25-38 and 105. It was completed on June 1669, and approved on 4 March 1670, published as: De Sinensium ritibus politicis acta. Paris: Nicolas Pépie, 1700. 
rati, three other Jesuits collated his writings and translated his philosophy from Chinese into Latin. ${ }^{20}$

II.

\section{The Dominican Father Domingo Navarrete flees from the Canton exile}

While all this was being done to unify the missionaries and to inform the Sacred Congregation, at the end of 1669, one of the twenty-three exiles suddenly left Canton without even his confrères from the same Congregation knowing about it, either because he was bored by exile and prison, or because he did not see any hope that Christianity would be restored, or because he was afraid of the work to be done later in this vineyard of Christ to which he came not called by God but by accident, as he would often repeat. (Father Philippe Couplet writes about it in his Report, and Father Grelon in his Annual Letter). ${ }^{21}$ His rather unexpected departure made everyone upset and frightened both because of the post that he had deserted and because of the fear of serious danger to which this exposed them, namely that some new persecution may start, or that their negotiations then being conducted at the Court [in Beijing] may be delayed. As in other times, however, in this crisis Divine Providence wanted to manifest its power by veiling the eyes of the Canton mandarins keeping guard over everything. As a result, they neither noticed nor even suspect what happened. To ensure greater secrecy, all the Fathers agreed that someone should be called from Macau to occupy the deserted post and assume the fugitive's Chinese name so that the original number of exiles would be maintained. ${ }^{22}$

${ }^{20}$ After the departure of Intorcetta from Canton, Philippe Couplet, Christian Herdtrich and François de Rougemont continued to work on the translations of the Confucian classics, published in 1687 in Paris as Confucius Sinarum Philosophus. Are mentioned the works of Sarpetri, Intorcetta and Le Faure, but there are other documents in response to Navarrete, for example Andrea Lubelli, Reposta à alguns pontos que escreve o Illustrissimo Navarrete; ms. BNF Espagnol 409: 192-196 (unpublished).

${ }^{21}$ This refers to Navarrete who escaped Canton on 9 December 1669. For the account of his departure (salida) and his own justification, see Navarrete, Tratados historicos. Madrid, 1676, p. 358; English translation: Awnsham Churchill, A Collection of Voyages and Travels, vol. 1. London: 1704, pp. 288-289. Szpot makes reference here to: Couplet, Breve relatione dello stato e qualità delle missione della Cina, ARSI Jap.Sin.131; and Grelon, Litterae annuae, V. Prov. Sinensis, of the years 1669 and 1670, dated 20 October 1670; original (3a via) ARSI Jap.Sin.122: 326-363; copy made in Rome ARSI Jap.Sin.120: 1-201. For the departure of Navarrete, see Jap.Sin.120: 180.

${ }^{22}$ Navarrete was replaced by the Jesuit mathematician Claudio-Filippo Grimaldi as explained below; he took the same Chinese name, Min Mingwo. 


\section{Dominican Father Francisco Varro sent in exile to Canton to join the others}

It happened that in the same exile there already was Father Francisco Varo from the Order of Saint Dominic. During the persecution, he hid for some time in the city of Funing, Province of Fujian, but at last was dragged out from his hiding place by a police prefect who was bitterly hostile towards the Christian religion. Varo was thrown into jail in the city of Fuzhou, the capital of that Province. After the whole matter was brought to the Court [in Beijing], the Tribunal of Rites ordered the Father to be transferred to Canton with the other exiles. $^{23}$

\section{Father Filippo Grimaldi replaces Father Navarrete}

Varo could not replace the fugitive because he was an addition to the missionaries and his name was inscribed separately in the public registers. Thus the Fathers decided to use a holy deceit and wrote to Macau that Father Filippo Grimaldi should put on a disguise and come as soon as possible to Canton to join the others. He did not delay. With his speedy arrival he both allayed the Fathers' anxieties and dispelt the danger of capital punishment that would have been imminent if the escape of Father Domingo Navarrete had been noticed. ${ }^{24}$

\section{Navarrete returns to Europe and publishes a book maligning the Society of Jesus in China}

Although Navarette's secret escape took place under such bitter circumstances, since he took part in the toils and afflictions suffered for the law of God and was an outstanding promotor of the peace and unity among them, the missionaries found comfort in the hope that he would do in Europe what they needed in these circumstances for the greater glory of God as well as the benefit and honour of the Chinese mission. However, their hope was deceived by his book which he published in Spanish. It was truly offensive to Chinese antiquity, which he considered lacking any knowledge of the true God and

${ }^{23}$ On 28 June 1669, the Dominican Francisco Varo (1627-1687) was arrested in Fujian, and only on 24 February 1671, he was deported from Fuzhou to Canton which he reached on 13 April 1671.

${ }^{24}$ In fact, Grimaldi who arrived Macao in 1669 came to Canton sometime in 1670, while Varo was transferred to Canton in April 1671. 
reward after death for good and evil deeds. (See Father Philippe Couplet's above-mentioned Report). The book was biased against the great labours undertaken by the missionaries over one century for the conversion of China; actually, he did not hesitate to assert that they were in horrible error. ${ }^{25}$

Both information that the representatives of Chinese mission had already given to the Holy See and some apologetic writings by famous missionaries from the same order to which he belonged ${ }^{26}$ protested his very presumptuous statements. Yet, when all the missionaries in the Indies [i.e. in Asia] were embroiled in a certain storm, the contents of this book seemed believable, or at least diminished or put in doubt the beliefs about China which until recently were considered indisputable.

\section{Our Fathers write apologies against him}

Thus the missionaries in China once again had to make recourse to apologetic writings. In some measure, the enemy was fortified with his defences. They had come to battle and subject him to the divine law. Content with besieging him, they turned to battle him. The more dangerously he attacked them, the more violently he destroyed their works and reputation, wrecking their labours and oppressing their spirits.

Therefore, Father Giandomenico Gabiani, then the Vice-Provincial of the Society of Jesus in China, composed the "Apologetic dissertation about the responses given by the Holy Inquisition to the missionaries of the Society of Jesus and confirmed with the pontifical authority in $1656 " .{ }^{27}$ To this he added an apologetic "Appendix" about the knowledge of the true God and the spiritual things in China, and about the legitimate use of the Chinese words by with God and spirit are expressed. ${ }^{28}$ Besides that, he composed also an apologetic "Synopsis" of the complaints against the Jesuit missionaries in China. He

${ }^{25}$ See Navarrete, Tratados historicos. Madrid: 1676.

${ }^{26}$ This is a reference to Sarpetri.

${ }^{27}$ When the Jesuits in China received the Tratatados of Navarrete, they prepared their answer. Gabiani was vice-provincial of China in 1680-1683, and he wrote in 1680: De ritibus ecclesiae sinicae permissis apologetica dissertatio; Prima pars: Lucubrationum ad Objectarum Controversiarum et Suerclationem Conducentium (53 plus 20 punta); Secunda pars: Elenchi conclusio universalis (4 punta), Tertia pars: Singularia ex elencho deducta corollaria (14 punta), Ajuda 49-IV-62.1682, ff. $651-667 \mathrm{v}$.

${ }^{28}$ Apologeticae dissertationis appendix, 1680 (BNF Espagnol 409: 159-188), of which the folios $131 \mathrm{v}-153 \mathrm{v}$ were printed as: Dissertatio apologetica, scripta anno 1680, de sinensium ritibus politicis (Liège: G.H. Streel, 1700). See Henri Bernard-Maitre, "Un dossier bibliographique de la fin du XVIIe siècle sur la question des termes chinois," Recherches de Science Religieuse 36 (1949): 63-79. 
composed all these writings in $1680 .{ }^{29}$ Father Lodovico Buglio, who spent forty-five years as a missionary in China, wanted to crown his labours in his old age by writing the "Short response", which was finished in 1680. This work rebutted the book which lambasted the Jesuits' missionary practices for evangelizing China. ${ }^{30}$ Father Ferdinand Verbiest, leaving aside for a while his work in astronomy, produced an apologetic answer to some doubts which were proposed to the Sacred Congregation and insulted the Jesuit Fathers in Beijing. ${ }^{31}$

The last in their number was Father Francesco Saverio Filippucci. After he became the provincial of Japan in 1680, he wrote all together seven treatises. ${ }^{32}$ In the first of them, which he entitled "Notes", he showed that the translations of the Chinese texts used by that author [Navarrete] were completely false because of his ignorance of Chinese characters. ${ }^{33}$ In the second, he answered the false accusations against our missionaries that in practicing the Chinese traditions the Society acted in bad faith, and that Father Martino Martini, when sent by the China missionaries to Rome, gave to the Sacred Congregation incomplete and unreliable information. ${ }^{34}$ In the third, he discussed Chinese rites established to honour the memory of the dead. ${ }^{35}$ In the fourth, he candidly explained thirty-seven Chinese texts concerning civil rites and gave answers to the doubts proposed. ${ }^{36}$ In the fifth, he set forth some notes and judgements on some classical Chinese books. ${ }^{37}$ In the sixth, which was written in 1682 ,

${ }^{29}$ Giovanni-Domenico Gabiani, Elenchus elucubrationum ad objectarum controversiarum elucidationem conducentium, 22 September 1680, Canton; in Henri Bernard-Maître, "Un dossier bibliographique de la fin du XVIIe siècle sur la question des termes chinois," Recherches de science religieuse 36 (1949): 33-79.

${ }^{30}$ Unknown text.

${ }^{31}$ Ferdinand Verbiest, Responsum apologeticum P. Ferdinandi Verbiest Societatis Jesu ad aliquot dubia, BVE Fondo Gesuitico 1257 /33; Archives Province de France, Brotier 104. It was written between 5 October 1680 and September 1681. The Latin text has been published twice: Henri Joson \& Léon Willaert, Correspondance de F. Verbiest, Bruxelles: Palais des Académies, 1938, pp. 279-342; Noël Golvers, Letters of a Peking Jesuit: The Correspondance of Ferdinand Verbiest (1623-1688), Leuven: Ferdinand Verbiest Institute, 2017, pp. 339-393.

${ }^{32}$ He was provincial of Japan from 1680 to 1683 , and from 1688 to 1691 visitor of Japan and China.

${ }^{33}$ Notae on the Liji, Shijing, Yijing and Jiali, quoted in François Noël and Gaspard Castner, Summarium Novorum Autenticorum Testimoniorum, Rome, 1703; see Standaert, Chinese Voices in the Rites Controversy. Rome: IHSI, 2012, p. 75.

${ }^{34}$ Unidentified. In 1656, Martino Martini (1614-1661) had obtained from pope Alexander VII the authorization for the Chinese rites.

${ }^{35}$ Unidentified.

${ }^{36}$ Explicatio 37 textuum Sinicorum, BVE, Fondo Gesuitico 1383, n. 11, ff. 70-101.

${ }^{37}$ Tractatus Patris Francisci Filippucci de Ritibus Sinicis quem in suo Praeludio promittit. Hunc Tractatum in Archivio Macaensi abtulimus anno 1707. Liber primus etiam manu Patris Philippucci descriptus, sed minus legibilis relictus est in eodem Archivio macaensi. Gasparus Castner; BVE Fondo Gesuitico 1248/3, 115r-302r. See Eugenio Menegon, European and Chinese Controversies over Rituals: A Seventeenth-Century Genealogy of Chinese Religion, in Socio-religious Models, 
he demonstrated four points: firstly, that the seventeen questions submitted to Rome during the pontificate of Innocent X contained forty-two false statements; secondly, that the answers of the Sacred Congregation were not faithfully translated into Chinese but were inaccurately abridged with very poor skill in the Chinese language; thirdly, that important points were omitted in this translation done in China, including those which favoured the Jesuit missionaries and the Chinese people; fourthly and finally, as he visually demonstrated, those who attacked the missionaries in China in such an important issue did not proceed honestly. ${ }^{38}$ His last treatise, which he entitled "The Twisted Arrow," was about the same controversies. ${ }^{39}$

\section{The Illustrious Bishop of Basilitanus writing in favour of the Society}

oreover, the distinguished and Very Reverend Father Gregorius Lopez from the order of Saint Dominic, titular bishop of Basilitanus, did not abandon the missionaries, whom he would later have under his jurisdiction. As a Chinese person from the Province of Fujian and expert in the rites of his people, he composed in his mother tongue and published books in which he defended the statements and good name of our missionaries, writing about them with approval and praise. ${ }^{40}$ We have already mentioned that earlier, when he was not yet bishop, he was secretly called by our Fathers to help the Church which was deprived of its pastors, and that with great zeal he brought solace to the neophytes in the provinces he visited.

The erection of these defences blunted the brazen impetuosity of the enemy at home and somewhat calmed down the tempest, which was more serious because the missionaries endured it for preaching God's law and would be deprived of the glory of suffering persecution for Christ, while they were toiling to plant the faith in these huge regions and sweating from the constant fear of new dangers. All what we have related until now concerning the establishing of the agreement and unity among the missionaries exiled in Canton, needed to be discussed in another place, but because no more convenient place might be given to domestic tensions, we have recalled all that with the story of the exile in Canton and of the deserter [Navarrete].

Rituals, and the Performativity of Practice, ed. Bruno Boute and Thomas Smaberg. Leiden: Brill, 2013, p. 218.

${ }^{38}$ Praeludium ad plenam disquisitionem an bona vel mala fide impugnentur Opiniones, et Praxes Missionariorium Societatis Iesu in Regno Sinarum, Macao, 23 March 1683, BVE 1249/7. This was partially published in: De Sinensium ritibus politicis acta. Paris: Nicolas Pépie, 1700.

${ }^{39}$ Sagitta retorta, seu sagittae in innocentes gratis intortae in ipsos jaculantes defensionis gratia retortae, BVE Fondo Gesuitico 1247/8, 223r-311r; 1247/9, 316r-424v.

${ }^{40}$ Unidentified. 
III.

\section{Deliberation of Canton and Beijing Fathers about admitting Chinese to the priesthood}

Once these resolutions had been reached in view of a uniform missionary praxis, as we have discussed above, they were applauded by all, including those who learnt about them by letters. The Fathers then were worried about how to provide qualified missionaries who would preach the same divine law as they were preaching, and who would not only protect and defend it during any persecution, but also would use their own zeal, doctrine and virtue to promote the conversion of the entire empire (Letters by Father François Rougemont written from Canton, 6 March and 26 August 1671, and other letters). ${ }^{41}$

\section{Reasons to admit Chinese to ordination: First, the great difficulty in having always European priests due to the distance}

It was always obvious that reinforcements from Europe were slow to arrive and uncertain. Most [priests] would be devoured by the ocean and the long journey. Even those who arrive safe and sound, before starting work, would need years to learn such a difficult, almost hieroglyphic, language and to be able to read Chinese books so that they could become the missionaries that China needs. Furthermore, the experience of past years has shown that, even if some with talent, good character and skills arrive and learn Chinese well, just because they are foreigners and Europeans, they can never be sure of having the chance to set foot in China.

\section{Second, the arrogance of the Chinese who disdain foreigners}

Everybody knows that the Chinese literati, who inherited an age-old wisdom, are innately arrogant and hold foreigners in contempt. Thus whatever is brought to China by foreigners, regardless of whether it concerns divine or human affairs, will indeed be silently admired, but will nonetheless be despised because of its foreign origin. We have already related in our above discussion on the re-establishment of the European astronomy that this criticism was even made by the Tartars' gelao or imperial minister against other Chinese mandarins. When petitioning the restoration of the divine law to its previous position, our [priests], who enjoyed the trust of the Tartars, objected to this accusation which was made the Chinese despite acknowledging that [Christianity] con-

\footnotetext{
${ }^{41}$ Unknown letters.
} 
formed to natural reason and was blameless and not only free from any vice attributed to it by Yang Guangxian but also perfect in every aspect and wellproven by experience.

\section{Third, the fear that the Chinese and the Tartars have of foreigners}

The reason for this presumptuous esteem of their own things is not only the fear of foreigners that the Chinese have, but also the Tartars' awareness of their minority status in China. They undoubtedly started to fear the Europeans because of their strength, intelligence and power that became evidence both from many embassies and from the strong fleet of the Dutch, who brought order to the Chinese Sea earlier infested by pirates. So, it seemed almost miraculous that the Chinese did not reward the Dutch for their many merits with even one house to conduct commerce. Yet they allowed Europeans dispersed throughout all the provinces of the empire to stay for a long time and even replenish their numbers to promote the teaching of the divine law.

\section{Fourth, the fragile security of the European astronomy}

Some security would seem to be promised by the fact that European astronomy was well established in the Royal City and enjoyed the favour of Princes and other noble personages at Court. However, the example of Father Adam Schall showed that everything was not secure and could disappear at any moment because the favours of the Princes are inconstant and character of the Chinese fickle.

Even now there are people who oppose and plot against European astronomy. I read this in the book of the infamous Yang Guangxian: "It is unworthy of the emperor and of the Chinese name to reform our own calendar according to the rules of European astronomy. This is nothing else than to subject the vast and flourishing empire to a small, foreign kingdom." Others like Yang Guangxian could rise up, for China is always full of people who are just as spineless as stubbornly attached to their habits and traditions, and extremely jealous of the flourishing fortune of others, especially foreigners. They storm against our astronomy and the preachers of the Gospel. They would expel European priests, who are very easy to recognize, not only from Canton, but also from overseas. After destroying Macau, the only gate to China that the European priests have-something which they had already attempted-they would shut forever the entrance to the empire. In such a situation, who will take care of the thousands of souls that the missionaries submitted to the divine law and 
Christ with years of sweat and labour? Who will ensure that they do not return to their old sects and superstitions, either out of fickleness or because they are bereft of pastor, teacher and culture? With the departure of those who were commended by their fervour, dedication to their new religion and virtues worthy of the altars, will not they turn to wild idolatry as they gradually lose sense of evil and their customs are corrupted?

\section{Fifth, the examples of other nations converted to Christianity}

Thus China has to be saved by China, and it is important that the work and ministry of the indigenous people not only preserve the Christian religion, but also promote in the whole empire the conversion promised by Divine Mercy. This is suggested by the examples of all the churches in the world that were bequeathed to posterity by apostolic men who brought the Gospel to various kingdoms and peoples. Furthermore, the inflexible laws that forever prevent foreigners from entering and dwelling in China, necessitate that its extremely suspicious and shy people who are severely forbidden from having any contact with foreigners are evangelised by people from whom they have nothing to fear and a lot to hope. Even when Christians are persecuted, these people would easily be able to hide or appear in public and bring help to those in need. Among the many thousands of Christians, there are literati and teachers of the Chinese sciences who are endowed with a zeal for promoting the Christian faith and constant virtue and also feel called by God to such an excellent ministry. Their faith, which has been tested by many trials, proves that they are able to work for the salvation of souls, while their outstanding teaching leaves no doubt that, after eradicating Chinese errors with their own philosophy, they will establish Christian truth and make the law of God, which is now only foreign in China, an indigenous resident of China. This is why both the Fathers in Canton and at the Court in Beijing are in favour of Chinese priests.

IV.

\section{Some oppose the deliberations of the China Fathers}

This very useful plan of the Fathers in China was opposed by those in Macau, who were completely ignorant of Chinese matters because they looked upon the vast empire of China in its entirety as if from a shore. ${ }^{42}$ Certainly, they understood the need to choose some Chinese to be ordained and to work

\footnotetext{
${ }^{42}$ In the revised version, Szpot mentioned as opponents to the Chinese clergy: P. Valguarnera, et P. Marinus aliique Macaenses; see ARSI Jap.Sin.109: 135. The Sicilian Tomasso Valguarnera (1608-1677) was in Siam in 1655-1668, and returned Macao in 1669, becoming the Visitor for Japan and
} 
for the conversion and salvation of their compatriots' souls, but they could not accept that such a choice be made from Chinese more advanced in age. They were perhaps influenced by new priests in Tonkin who were sent there by Pierre Lambert, bishop of Beirut, to spread the faith. ${ }^{43}$ Natives of that region, they had received the ordination and were admitted to the altar, but their poor Latin brought more discredit to the Christian religion than profit from their work among the pagan people. That was the reason of the fear that those chosen from older Chinese and destined to the priesthood would be the same. ${ }^{44}$

Given that Chinese characters hardly correspond to Latin syllables and words, and that the Chinese and Latin accents are completely different, Latin pronunciation is just as difficult for the Chinese as it would be for a boy to move heavy stones. Furthermore, Latin words pronounced in a Chinese accent have very different meanings. Thus it was feared that this deformation of the Latin pronunciation would produce meaning that is so deformed that the sacred mysteries of our Christian faith would be dishonoured and would be seen by the Chinese as a ridiculous abomination akin to comedy.

There was also another hidden reason for introducing Latin into China and establishing its use there. It was decided to establish a seminary in Macau where some young men from China would be sent to learn Latin and Christianity and later be trained as missionaries. This would be better than risking the contempt of divine things by ordaining older Chinese.

\section{Reasons why the China Fathers favoured the use of Chinese language in liturgy}

But the Fathers in Canton or in Beijing had studied more deeply the Chinese character and gathered from the customs of the court, which was like a microcosm of the whole Chinese empire and hidden to others, that nothing was more important than to have the liturgy held in Latin and for the Chinese youth either learn Latin or to be sent to Macau, or to wait until these young men were instructed in Latin and piety and experienced before entering the mission field. They had in their favour a privilege given by Pope Paul V after careful deliberation with the cardinals. This privilege, which still remained in effect but had not been put in practice because of the difficulties at the time,

China in 1670-1674, based in Macao. The Genoan Giovanni Filippo De Marini (1608-1682) spent many years in Tonkin, and was the provincial of Japan in 1670-1673, also based in Macao.

${ }^{43}$ Pierre Lambert de la Motte (1624-1679) arrived in Siam in 1662, and in 1670 went to Tonkin.

${ }^{44}$ The French Apostolic Vicars has requested in 1658 the authorization from Rome that the Chinese could say Mass in Chinese language; see Bosmans, "Documents relatifs à la liturgie chinoise," p. 276 
conceded to future Chinese priests permission to celebrate Divine Mysteries in their own language, though not in the popular one, but in the one used by the literati in China. ${ }^{45}$ Evidently, there were weighty reasons for which this provision of the Holy See was granted to the Chinese who for centuries had been separated from the rest of the world and had no contact with other peoples. In the past, other popes had already benevolently granted the same permission to Maronites, Armenians, Ethiopians, Slavs and other nations to which the Romans had brought their language together with their arms.

It is known that in China people are so attached to their language and writing, that they think the more their language avoids mingling with foreign nations, the purer it remains, while their writing is kept unsullied in its youthful prime. In this way, the Chinese think that their empire will be more prosperous and that the governmental wisdom of the empire will rule forever with its characters as if it were enclosed by a moat. Hence it happened later that even the Tartars who ruled China, in order to adapt themselves better to the character of the Chinese and to gain their affection, decreed by legal provisions and capital punishment that no Chinese learn their language and writing, although it is natural that all people, especially those who conquer and rule foreign nations, believe that their own glory and that of their nation is magnified by not only deeds but also the use of their mother tongue.

\section{Danger of introducing Latin language in China}

Given their great love for the language that they have used for thousands of years, who would impose any foreign language on those who show contempt for foreigners by having nothing to do with them and would not have any desire to know them? Who would dislodge from her throne a Queen, who has been adored in her country for ages, and put in her stead an unknown one, placing her in such an elevated position that she alone can speak about divine things, while the other one will be seen by her adorers as disdained and lying at the footstool of the throne?

And if you think that only those should learn Latin who are destined to be ordained and work for the salvation of the others and the promotion of the God's law, leaving aside the enormous cost of hiring teachers of both languages which China will not cover, a double danger is to be feared: first concerns religion and the second renewed persecution. It is known that the Chinese people are equally clever and suspicious. If Latin is introduced for the divine things and only the disciples of the European priests understand it, this will undoubtedly raise political suspicions of secret consultations aiming at

45 This was granted in 1615 . 
State's destruction by the Europeans. For instance, at present only very few priests celebrate the Divine Mysteries at the altars in Latin. Yet it is impossible to avoid serious prejudices against them. For that reason alone, all Christian gatherings and the distribution of sacred images are subject to the emperor's strict prohibition, though the public assembly declared the God's law innocent, and the esteem of the emperor himself show that such accusations could not be made against the European priests. What will be decided in the future, when many use a foreign language either to speak among themselves or even just in the celebration of the divine offices, if we do not enjoy the emperor's benevolence? The favours or hostility of the mandarins over the entire empire depend on his will. Oh how great an evil is mistrust! Even in peace and security, it sees dangers and wars; in innocent friendship and habits, it fears crimes, which have to be punished with blood, life and loss of wealth and good name!

Indeed, everyone can see the danger posed for the purity of the Christian faith by the sharp and inquisitive minds of the Chinese if they learn Latin. The Dutch have already started to have some commercial contacts with China; others will follow. Thus, it is possible that books will be brought here containing not only different teachings but also heretical dogmas, lies, slander, stories about the wars among Christian Princes, schisms and other monstrosities which will be used to reproach the integrity of the Catholic faith. Till now these new Christians have been so unaware of all this that they believe that all Christians all over the world share the same mode of expression, customs and mind, and are bound by a common faith and mutual charity. If from the reading of Latin books, they learn other things, what scandals would be produced among this curious people? What would they think about the orthodoxy in faith? What moral corruption and other obstacles to the embrace and promotion of God's law would follow? The examples of those who dwelled for a long time in Macau show that, although they saw only Catholics in this international marketplace, after seeing bad habits of some (such is the fragility of human nature), they bring them back home, and it takes a long time and effort to heal them.

Those who have deep knowledge of China [have written] many other points in other places on why Latin should not be introduced into this country. As we have already said, there was also a hidden reason which was mixed with certain European interests. In the end, this reason pushed those who wanted to establish Latin in this empire to nullify all the concerns of the legates sent from China and their reasons for using Chinese in worship after contrary information was sent to Rome. This greatly impeded a swifter conversion of the empire to the faith. ${ }^{46}$

${ }^{46}$ In a marginal note in the revised chapter, Szpot mentions his source as the related discussion by Philippe Couplet in his Relation: P. Philippus Couplet in sua Relatione de Lingua Sinica et 


\section{Training young Chinese not as easy as one thinks}

As for teaching language and religion to Chinese youth in Macau and preparing them to be future missionaries, the Fathers thought that this assistance would arrive too late for the Mission and that the situation of Christianity in China deprived them of security, in spite of the emperor's favours. In fact, even the grace of the princes that our Fathers experienced at Court, caused increasing jealousy among their rivals and that delay that the Jesuits in Beijing experienced in restoring God's law to its former state, threatened danger. What was required were older people, with solid virtue and zeal hardened by vicissitudes, and not inexperienced youth, who give more hope than fruit, though they seem to have much virtue. The natural disposition of the young, especially among the Chinese, is fickle. If the mature age does not press on them, they easily abandon the good decisions that they had earlier taken. Although we can hope that in time they would learn thanks to their teachers' vigilance and good example, but this would require many years and is not feasible for the present situation.

To this, we have to add that it is easier to find, among so many thousands of Christians, outstanding literati with well-tested virtue who are already living an exemplary Christian life of celibacy after being freed from matrimony [following the death of their spouse], than it is to find younger men not yet bound by matrimony. In fact, it is traditional for the Chinese to be bound by their parents in matrimony from childhood. Thus, in China a young man without wife is as rare as a phoenix. On the other hand, to buy boys from their parents and teach them from their young age the virtue and knowledge necessary for becoming a worker in the Lord's vineyard, as some suggested, would cause expensive conflicts, because of the volatility of parents who would even lie in court to have their children back once they have grown up. It would be shameful for Christian religion and God's law, if European slaves bought with money were to preach to the people who are so jealous of their honour and importance. Thus, the instruction of the Chinese youth has to be left for better times, while the present necessities and other reasons require that we make use of men and resources that have already been made ready for apostolic ministry.

Once this gathering of China Fathers reached these conclusions and added some other requests, it chose the Sicilian Father Prospero Intorcetta as their

Dissertatio cuisdam de Lingua Latina in Sinas non invehenda... Jap.Sin.109: 135. In this passage, Szpot seems to refer to Pierre Lambert de la Motte and other French Apostolic Vicars who had sent to Rome negative opinions about the ordination of local priests due to their inability to say Mass in Latin, so that Intorcetta and Couplet, sent as procurators to Rome, did not succeed in obtaining the authorization for a Chinese liturgy. 
delegate to the Holy See and to the Superior General of the Jesuits, Gianpaolo Oliva, and dispatched him to Rome. ${ }^{47}$ In order to hide his departure from the mandarins of the Guangdong Province they had to maintain the same number of exiles, just as it had been done earlier when Father Filippo Grimaldi replaced Father Domingo Navarrete. ${ }^{48}$ Thus, Father Emmanuel de Sequeira was called from Macau to replace Father Prospero. He was Chinese, who in his youth had been sent to Europe and to Roman Curia; he came back to Macau and to China after finishing his studies of philosophy and theology. ${ }^{49}$ Yet, it seems more probable for Father Prospero to be replaced by the French Father Germain Macret, ${ }^{50}$ or by the Savoyard Father Carlo Della Rocca, who died the same year, ${ }^{51}$ because Sequeira being Chinese could not replace a European missionary. (Father Intorcetta, sent to Rome as Procurator, is replaced by Father Emmanuel de Sequeira, or by Father Germain Macret. Father Couplet writes in his Catalogue that Macret came in 1664 from Macau to the Province of Fujian and died there in 1676. From this it is to be concluded that he came from Macau to Canton the same year and remained there when the persecutions started, and that later he replaced someone else in jail, and when the Fathers were allowed to returned to their churches, he went to Fujian. In any case, it is uncertain who replaced Father Intorcetta. $)^{52}$

${ }^{47}$ In fact, Intorcetta was elected procurator during the Jesuit provincial congregation held between 1 and 18 October 1666. The discussion on the Chinese clergy and liturgy between Jesuits happened on October and November 1667.

${ }^{48}$ Here again the chronology is incorrect. Intorcetta was the first to leave Canton, on 10 December 1668, and he sailed from Macao on 21 January 1669. Navarrete left Canton on 9 December 1669.

${ }^{49}$ Zheng Weixin (1633-1673) entered the Jesuits in Rome in 1651 and returned to Macao on 19 August 1668. He was the first Chinese to become a Jesuit priest, being ordained in Europe in 1664. With the missionaries in Canton, there was only one Chinese Jesuit brother, António Fernandez, or Cai Anduo (c.1620-1670).

${ }^{50}$ Germain Macret (1620-1676) had arrived China around 1658-1659, and he was not arrested during the persecution, finding refuge in Macao in 1666.

${ }^{51}$ Carlo Della Rocca, born in 1613, was active in Vietnam, Cambodia, and Hainan island. He died in Canton on 10 June 1670.

${ }^{52}$ When the persecution started in 1666, Macret did not stay in Canton, but took refuge in Macao. Therefore, he could perfectly replace Intorcetta. 
Tomasz Ignacy SzPot Dunin, “Collectanea historiae Sinensis” Tomus II, Pars II, Caput V

ARSI, Jap.Sin.104, f. $233^{\text {v }}-239^{v}$

\author{
Translation by Robert Danieluk, ARSI, ${ }^{53}$ \\ Revised by Daniel Canaris, Sun Yat-sen University
}

The transcription below has been prepared according following rules:

1. In what concerns paragraphs, punctuation and the use of capital letters, I do intervene in the text in order to facilitate its understanding; however, I try to be as respectful as possible of the style and spelling of the author

2. The abbreviations have been solved

3. The distinction between " $u$ " and "v" was introduced following what suggests the contemporary phonetics, e. gr. when the author writes "tractauit" and "breuem", I transcribe it as "tractavit" i "brevem" (cfr. f. 235"), etc.

4. The question mark in the square brackets [?] indicates the passages where I am not able to read the text, or where I am not sure of having red it correctly, e. gr. F[rater?] (cfr. f. 234 ${ }^{\text {r }}$.

[233v] Caput V: De actis Patrum Cantone in exilio degentium.

I.

Inter has sociorum Pekinensium curas restituendae in integrum rei christianae consecratas, Cantonienses exules, collato cum iisdem per literas consilio, laborabant: quibus mediis promovenda conversio deinceps tam vasti imperii, et inter ipsas persecutiones, si quae ingruerent, conservanda foret religio christiana.

Recensuimus parte I statuta illius concilii Patrum inter carceres celebrati, multis sessionibus agitata et uno omnium consensu ad unam eandemque missionariorum praxim circa administrandorum sacramentorum legisque Divinae praedicandae modum ac nonnullos ritus Sinis proprios observandos stabilita. Haec omnia, cum in bullis Pontificum, Sacrae Congregationis de Propaganda Fide institutionibus et declarationibus Sacrae Universalis Inquisitionis Alexandri VII authoritate roboratis, fundarentur, sublatura omnem sentiendi opinandive diversitatem, inimicam charitatis, quam apostolicum munus exigit, videbantur. Atque utinam eo animo et spiritu fuissent accepta ab iis, qui po-

${ }^{53}$ We thank Father Brian MacCuarta, S.J., academic director of ARSI, for the permission to publish the Latin transcription of this document. 
stea Evangelium praedicaturi Sinas intrabant, quo ab antiquioribus evangelicis viris, eadem ipsa, variis tot annorum experimentis iudicata, agnita et hoc ipso concilio Patrum e tribus sacris ordinis religiosorum congregato digesta et omnium voluntate confirmata fuere (Pater Philippus Couplet in sua "Relatione" ad Sacram Congregationem).

\section{Controversiae missionariorum Sinensium circa ritus Sinicos}

Sed ignoratio rerum istius imperii parque illi morum Sinensium cum caeteris, vel Americanis vel [234r] aliarum Indiarum populis aestimatio, eos in transversum egit, ut multa improbarent hocque nomine Societatem Iesu, prope uno seculo in Sinis laborantem, praeiudiciose simul ac iniuriose per ora ferrent in Europam, quasi illa superstitionibus Sinensibus conniveret, non Christum Crucifixum praedicaret. Ita nimirum "Confusius" ille mentem eorum confundebat et mortuorum parentalia vivam cuiuspiam irreligiosae actionis repraesentabant speciem, alia item nonnulla circa administrandorum sacramentorum rationem ad mores delicatos et pudicitiam muliebrem Sinensium accomodatam in opus absque errore minime deducenda censebantur.

\section{Patres missionarii e Societate Iesu infamantur a nonnullis per Europam}

Haec mala, cum retroactis etiam annis per illud imperium serperent et inde egressa in viciniores Indias adeoque in Europam penetrarent ac demum Romam ad delicatas in conservanda tuendaque sacrosanctae fidei integritate aures appellerent semperque fere ab inexpertis rerum Sinicarum eo penetratura et pacem in Sinis domesticam missionariorum perturbatura viderentur, in hoc ipso Cantoniensi exilio coacti sunt viri a literis, experientia, zelo vitaeque sanctimonia ac laboribus pro Christo in Sinis toleratis commendatissimi, nonnullos conscribere tractatus, quibus cum alios tum vel maxime Sacram Congregationem Fidei propagandae ac per illam Sedem Apostolicam, de omnibus Sinarum ritibus nonnullisque aliis inter missionarios controversiis edocerent.

\section{Patres exules Cantonienses ad sui defensionem apologias conscribunt}

Atque inprimis Reverendus Pater F[rater?] Dominicus Maria Sarpetri, seu a Sancto Petro, Ordinis Praedicatorum lector theologus, scripsit tractatum anno 1668, quo confutavit librum Patris Nicolai Longobardi e cineribus suis redivivum, defenditque praxim Patrum Societatis Iesu in usu nominum, qui- 
bus Deus, angeli et anima compellanda essent in Sina. Huic adiunxit authenticum testimonium, quo confirmavit praxim Patrum nostrorum versantem circa conversionem ad fidem Sinarum. Demum anno 1670 idem ipse elucubravit alium tractatum, cui titulum dedit: "Brevis notitia aliquorum ex fundamentis, ob quae permitti debeat christianis Sinensibus cultus Confucii et defunctorum, sicut iam eum olim permisit Sacra et Universalis Inquisitio tempore Alexandri VII".

Anno item 1668 Pater Prosper Intorcetta e Societate Iesu scripsit "Disputationem apologeticam de officiis et ritibus civilibus quibus Sinae memoriam recolunt Confucii et progenitorum suorum vita functorum". Eum secutus est Pater Franciscus Brancati, triginta [234v] quinque annorum in Sinis e Societate missionarius, anno 1669 et exaravit "Responsionem ad dubia proposita circa ritus Sinenses", additis ipsis textibus Sinicis. Eodem anno Pater Iacobus Le Faure ex eadem Societate, olim professor theologiae quam scholasticam vocant, Pictavii, edidit "Dissertationem theologico-historicam de avita pietate Sinarum erga defunctos et eximia erga Confucium magistrum suum observantia" cum appendice et epilogo.

\section{Confutius seu Confusius a nostris Patribus in Latinum versus}

Tandem quis esset ille Confucius quaeve doctrina ipsius, causa tantae apud literatos Sinenses venerationis, ut cognosceretur ex suis libris, collata opera tres alii e Societate Patres philosophiam eius e Sinica Latinam fecerunt.

II.

\section{Pater F[rater?] Dominicus Navarrete, dominicanus, ex exilio Cantoniensi fugit}

Dum haec pro stabilienda missionariorum unione informandaque Sacra Congregatione agebantur, unus ex illo viginti trium exulum numero, repente se Cantone, insciis etiam sui ordinis fratribus, sub finem anni 1669 clanculum subduxit, sive pertaesus exilii et illius carceris, sive desperata rei christianae restitutione, sive denique metu subeundorum postea laborum in illa Christi vinea, ad quam se non vocatum a Deo, sed fortuito venisse dictitabat.

Eius tam inopinatus abitus quanto dolore ob desertam stationem, tanto timore omnes perculit ob summum periculum, in quod sua fuga illos involverat, aut novae alicuius persecutionis excitandae, aut saltem retardandi negotii, de quo tum in Regia agebatur. Verum Divina Providentia, sicut in aliis ita in hoc discrimine, opem suam manifestare voluit dum vigilantibus ad omnia illis 
mandarinorum Cantoniensium occulis velum quoddam securitatis opposuit, ut non solum factum non adverterint, sed ne suspicati quidem fuerint. Quod ut melius lateret, consilium omnium Patrum fuit, ut quispiam Macao evocatus, desertam stationem occuparet, sumptoque profugi nomine sinico, numerum exulum impleret.

\section{Pater F[rater?] Franciscus Varro, Ordinis Sancti Dominici, in exilium Cantonem ad alios relegatus}

Erat iam in eodem exilio Pater F[rater?] Franciscus Varo, Ordinis Sancti Dominici, qui cum sub tempus persecutionis in civitate Fo-nim, Provinciae Fokien, aliquamdiu latuisset, tandem e latebris in lucem extractus a quodam militiae praefecto, infensissimo religionis christianae hoste, in civitate Fokeu, metropoli eiusdem provinciae, in carcerem coniectus et, delata re tota ad Regiam, a tribunali rituum Cantonem ad alios relegari iussus fuit.

\section{Pater Philippus Grimaldi in locum Patris F[ratris?] Navarrete succedit}

Hic quoniam supra numerum caeteris adiunctus fuit exulibus nomenque eius separatum publicis insertum erat tabulis, non poterat [235r] in locum illius succedere, dolo sancto utendum rati Patres scripserunt Macaum, ut quamprimum Pater Philippus Grimaldi, sumpto habitu ad sese occultandum idoneo, Cantonem advolaret sociis aliis adiungendus. Nec ille quidquam moratus est, suoque celeri adventu, cum animos Patrum metu sollicitos recreavit, tum periculum quod imminebat, si fuga Patris Dominici Navarrete innotuisset, a capitibus eorum amovit.

\section{Navarrete librum in Europam redux edit iniuriosum missionariis Societatis Iesu in Sinis}

Interea, licet acerbus ille clandestinus abitus supra memorati Patris acciderit, quia tamen idem ipse, cum particeps laborum et aerumnarum pro lege Divina toleratarum, tum vero concordiae et unionis inter missionarios stabilitae promotor eximius fuit, solabatur eos spes aliqua agendorum in Europa per ipsum quae ad Dei gloriam promovendam et utilitatem honoremque missionis Sinicae in tali rerum momento ab illis desiderabantur. Verum hanc spem eorum delusit ipsius liber, hispanico idiomate in lucem protrusus, iniuriosus sane antiquitati sinicae, a qua veri Dei notitiam bonorum malorumque post mortem sua praemia tollebat (Pater Philippus Couplet in citata "Relatione"), praeiudi- 
ciosus impensis integro saeculo ad conversionem Sinarum virorum apostolicorum laboribus, quos et faede errasse asserere non dubitavit.

Tam audacibus eius assertis, licet iam olim datae ab oratoribus Sinicae missionis ad Sedem Apostolicam publica fide informationes reclamarent et eiusdem sacri ordinis, ex quo ille fuerat, illustrium in ea missione operariorum editae apologiae scripto sese opponerent, in ea tamen tempora, quibus nescio quis turbo omnes missionarios Indicos tempestatibus suis involverat, codex ille inciderat, ut aut facile iis quae dicebantur in ipso crederetur, aut saltem minueretur et in dubium vocaretur ea fides, quae nuper de rebus Sinicis indubitata habebatur.

\section{Contra illum Patres nostri scribunt apologias}

Inde iterum ad apologias postea confugiendum erat missionariis Sinensibus et relicto nonnihil hoste suis munitionibus obvallato, ad quem expugnandum et Divinae legi subiugandum venerant, contenti sola obsidione ad eum se converterunt profligandum, qui tanto periculosius eos urgebat, quanto maiori violentia, adempta operum et nominis fama, labores eorum dissipabat et spiritum opprimebat. Elucubravit igitur Pater Ioannes Dominicus Gabiani tum vice-provincialis Sinensis Societatis Iesu, "Apologeticam dissertationem pro responsis Sacrae Universalis Inquisitionis missionariis Societatis Iesu datis et [235v] authoritate pontificia anno 1656 confirmatis". Huic adiunxit "Appendicem apologeticam" de cognitione veri Numinis et spiritualis substantiae apud Sinas legitimoque Sinensium vocabulorum usu, quibus Deus et Spiritus exprimuntur. Item "Synopsim apologeticam" criminationum in Sinenses Societatis Iesu missionarios. Haec omnia in lucem edidit scripta anno 1680.

Pater Ludovicus Buglio, quadraginta quinque annorum in Sinis missionarius, labores suos in senectute ultima voluit coronare et ad defensionem Sociorum edidit scripto "Brevem responsionem" ad librum improbantem praxim missionariorum Societatis Iesu in praedicando Sinis Evangelio, confectam eodem anno 1680.

Pater Ferdinandus Verbiest, remota tantisper ab astronomicis operibus manu, dedit responsum apologecticum ad aliquot dubia Sacrae Congregationis propositia, in quibus Patres Societatis Iesu Pekini degentes sugillari videbantur.

Ultimus in hoc numero fuit Pater Franciscus Xaverius Philippucci qui, cum esset eodem anno 1680 provincialis Iaponiae, septenos omnino scripsit tractatus.

Primo eorum, quem "Notas" appellavit, ostendit interpretationes textuum Sinicorum, quibus ille author usus fuerat, plane erroneas ex imperitia literarum Sinicarum fuisse. 
Secundo respondit ad calumnias nostris missionarii impositas, quasi in praxibus sinicis mala fide operaretur Societas, et Pater Martinus Martini, olim Romam Patrum Sinensium ablegatus, diminutas et parum fideles informationes dederit Sacrae Congregationi.

In tertio tractavit de ritibus Sinicis ad repraesentandam defunctorum memoriam institutis.

Quarto genuine explanavit triginta septem textus Sinicos circa ritus civiles cum suis responsis ad proposita dubia.

Quinto notas et censuras in quosdam libros Sinenses classicos exposuit.

In sexto, anno 1682 edito, quatuor probavit. Primum: septemdecim quaesita Romae, regnante Innocentio X proposita, continere duas et quadraginta suppositiones falsas. Secundum: responsa Sacrae Congregationis diminute, non fideliter et cum magna imperitia linguae Sinicae fuisse versa. Tertium: in dicta versione in Sina facta omissa fuisse puncta essentialia et ea quae missionariis Societatis Iesu ac Sinensibus favebant. Quartum demum quod ad oculum demonstravit: impugnatores missionariorum Sinensium, in re tanti momenti, non sincera fide processisse.

Ultimus tandem illius tractatus fuit circa easdem controversias, quem et "Sagittam retortam" nuncupavit.

\section{Illustrissimus episcopus Basilitanus pro missionariis Societatis scribit}

Non deerat etiam missionariis, quos [236r] postea suae iurisdictionis habiturus erat, Illustrissimus et Reverendissimus Pater F[rater?] Gregorius López e Divi Dominici Familia, episcopus Basilitanus, qui cum esset natione Sina e Provincia Fokien rituumque suae gentis peritissimus (quem prius tacito eius nomine vocatum a nostris Patribus, nondum eo tempore episcopum, in auxilium destitutae et orbatae suis pastoribus christianitatis, magno zelo suo et solatio neophytorum percursasse provincias diximus), hic inquam praelatus edidit in lucem e typo et lingua patria libros, quibus nostrorum missionariorum cum summa approbatione et laude sententias et famam vindicavit.

His propugnaculis excitatis retusus est impetuosus hostis domestici ausus et sedata nonnihil excitata tempestas, tanto gravior illa, quam pro lege Divina promulgata praedicatores Evangelii sustinuerant; quod pro plantanda in illis vastissimis regionibus fide laborantibus et inter continuos metus novorum periculorum desudantibus, gloriosum nomen toleratae pro Christo persecutionis adimeret. Atque haec, quae hucusque occasione stabilitae concordiae et unionis in Cantoniensi exilio inter promulgatores legis Divinae recensuimus, alium locum iure suo et tempore vendicabant, sed quia forte prosperiora, quam 
hactenus fuere spatium inter se domesticis perturbationibus non concederent, in exilium Cantonem illa cum desertore revocavimus.

III.

\section{Consilium Patrum Cantoniensium et Pekinensium de Sinis sacerdotio initiandis}

Postquam ea, de quibus diximus, ad uniformem missionariorum in Sinis deinceps praxim, statuta condita essent, et ab omnibus, etiam iis quibus ea per literas communicata fuerunt, recepta cum plausu communi, non minor cura et sollicitudo Patribus illis incubuit providendi idoneos operarios, qui eam quam ipsi praedicarunt legem Divinam, non modo inter persecutiones, si quae ingruerent, sartam tectamque conservarent, verum etiam zelo proprio, doctrina et virtute, ad maius incrementum adeoque totius imperii conversionem promoverent (Litterae Patris Francisci Rougemont Cantone datae 6 Martii et $26 \mathrm{Au}$ gusti anno 1671 aliorumque).

\section{Causae ob quas Sinae deberent sacris ordinibus initiari Prima: difficultas magna habendi semper sacerdotes Europaeos ob distantiam loci}

Obversabatur continuo in oculis, inprimis Europaea auxilia et tarda esse et incerta, quorum maximam partem oceanus et tam longinquum iter semper devorare soleret, et si qui integri sanique pervenissent, antequam ad labores accederent, in addiscenda illa per quam difficili ac pene hieroglyphica lingua evolvendisque Sinensibus libris, annos prius consumpturi essent, ut formarentur operarii qualibus opus haberet Sina. Deinde quocunque tandem illi numero venissent et quibuscumque animi artisque dotibus ac peritia etiam linguae Sini- [236v] cae instructi fuissent, eo ipso quod exteri sint et Europaei, secure ut pedem figant in Sinis, neminem sibi promittere posse, retro temporum experientia docuit.

\section{Secunda: arrogantia Sinensium qua despiciunt exteros}

Notam esse innatam arrogantiam possessae per tot annorum saecula, et in contemptu aliarum gentium enutritae literatorum Sinensium sapientiae. Quidquid demum seu Divinarum seu humanarum rerum eo ab exteris inferatur, transire quidem in taciturnam apud illos admirationem, hoc tamen ipso despici, 
quia ab exteris est. Id improperasse Tartarum Colao Sinae aliisque mandarinis, supra recensuimus, dum de restitutione astronomiae Europaeae egimus; id nostros confidentia quadam favoris Tartarorum obiecisse Sinensibus, dum de lege Divina in suum statum revocanda est supplicatum: cum tamen et istam rationi et lumini naturali conformem eamque innocentem et nulli vitio, quae impius Yamquamsien obiecerat, subiectam et illam suis numeris absolutam, perfectam et experimentis suis probatissimam, cum laude et plausu agnovissent.

\section{Tertia: timor et metus Sinensium et Tartarorum ab exteris}

Ad hanc praesumptuosam rerum suarum aestimationem, non minore ab exteris metu Sinas teneri atque Tartaros paucitatis suae in Sinis conscios. Qui cum Europaeorum vires, ingenium et opes, timoris sui non dubium argumentum, tum ex variis legationibus tum ex potenti nuper Batavorum classe, qua mare Sinicum infestum prius pyratis quietum reddiderunt, cognoscere coepissent, rem prope miraculo fore, ut qui Batavis pro tot eorum meritis ne unam quidem domum ad exercendum commercium in Sinis concessissent, ii, dispersos per omnes imperii provincias Europaeos diu morari patiantur, multoque minus ut novi novique accedant ad promovendum legis Divinae cursum.

\section{Quarta: astronomia Europaea fragile securitatis fundamentum}

Et quamvis Europaea astronomia, fixa iam sede in Regia et ex illa natae Regiae gratiae, regulorum et procerum Aulae favores, securitatem quandam promitterent, tamen haec omnia incerta esse et levi momento, ut sunt inconstantes favores principum et volubilia Sinensium ingenia, difflari posse, exemplum Patris Adami Schall commonstravit. Non deesse qui etiamnum astronomiae Europaeae adversentur et insidientur. Legi adhuc in codice infami Yam-quam-sieni: Indignum esse imperatore et nomine Sinico reformare proprium calendarium secundum regulam Europaeae astronomiae; idque non esse aliud quam subiicere uni exiguo et extraneo regno vastissimum et florentissimum imperium. Posse similes Yam-quam-sieno exurgere, quos nunquam deesse inter Sinas, gentem timidissimam aeque ac tenacissimam suorum morum traditionumque et fortunae alterius, praesertim exterorum, inter se florentis, maxime invidam, qui contra astronomiam nostram Evangeliique praedicatores excitent tempestatem, et Euro- [237r] paeos sacerdotes, quos ex ipso occursu dignoscere per quam facile est, non iam Cantonem, sed ultra mare abigant, et demolita Macao, unica porta sacerdotibus Europaeis in Sinas, ut iam attentatum erat, aeterno impedimento aditum illum in imperium occludant. 
Tali temporum statu, tot millibus animarum, quas labor missionariorum legi Divinae et Christo tantis annorum sudoribus submisit, quis providebit, ne aut per inconstantiam ad veteres suas sectas et superstitiones redeant, aut certe sine pastore, sine magistro et cultura, decedentibus etiam illis quos hucusque fervor et constans in suscepta religione spiritus virtusque sacris altaribus digna commendavit, pedetentim et sine sensu malorum, in corruptos mores et ex illis silvescentem idololatriam abeant?

\section{Quinta: exempla aliarum gentium conversarum ad fidem Christi}

Sinas igitur per Sinas salvandos esse, indigenarum opera et ministerio deinceps non solum conservari, sed etiam promoveri religionem christianam atque ad totius imperii, quam Dei misericordia promittit conversionem insudari oportere. Suaderi id omnium Ecclesiarum per totum orbem diffusarum omniumque temporum, quibus diversis regnis et populis invectum est Evangelium, relictis posteritati per viros apostolicos exemplis.

In Sina etiam adamantinas illas leges, quibus aeternum ab imperii aditu et incolatu exteri excluduntur, necessitatem quandam imponere, ut suspicacissimae et timidissimae illi genti, cui omnis conversatio et familiaritas cum exteris piaculum est, severeque animadvertitur, ii praedicent, a quibus nihil metui, plurimum sperari possit, et qui inter ipsas christianorum persecutiones, facile et latere et in apertum prodire ac laborantibus auxilium ferre valeat. Non deesse inter tot christianorum millia literatos et magistros scientiarum Sinensium, zelo promovendae religionis christianae sibique constantissima semper virtute praeditos, qui ad hoc ipsum tam excellens ministerium a Deo se vocari sentiunt. Eos sicut fides, variis experimentis probata, laboribus circa animarum salutem subeundis idoneos futuros promittit, ita doctrina eximia spem non dubiam facit, ut eadem, sua philosophia eversis erroribus Sinicis, veritatem christianam stabiliant legemque Divinam modo in Sinis peregrinam, indigenam et inquilinam Sinarum efficiant. In hunc modum pro Sinis sacerdotibus Patres, qui Cantone et qui Pekini in Regia commorabantur.

[237v] IV.

\section{Consilio Patrum Sinensium opponunt se nonnulli}

Tam utili Patrum Sinensium consilio opponebant se ii, qui velut e littore totum tam vastum imperium Sinarum Macao prospiciebant, rerum Sinicarum prorsus ignari. Necessitas quidem deligendorum e Sinis, qui sacris ordinibus initiarentur adeoque conversioni et saluti animarum deinceps inter suos indigenas vacarent, illis in aperto erat, sed ut ex maturioribus aetate Sinis iste de- 
lectus fieret, id demum sustineri non poterat. Movebant eos nescio qui novelli mystae in Tunkino, a Petro Lambert episcopo Berithensi, eo ad propagandam fidem missi, ex illa gente sacris initiati et Divinis altaribus admoti, qui plus dedecoris sua imperitia linguae latinae, quam laboribus inter gentiles suos cuiuspiam proventus christianae religioni attulerant, indeque timor animos incesserat, ne forte tales illi futuri essent, qui ad altare Christi e Sinis maturioribus admovendi assumerentur.

Cum enim tam ob defectum characterum Sinensium qui corresponderent Latinis syllabis et dictionibus, quam ob diversitatem accentuum toto coelo a Latinis discrepantium, pronunciatio Latini sermonis aeque difficilis Sinensibus fieret, ac puero ingens loco movere saxum, ipsae vero syllabae Latinarum vocum ad accentum Sinicum prolatae, res plane diversas significarent, verendum erat ne ex illa corruptione Latinarum vocum nascerentur rerum significatarum monstra, quae sacra nostra mysteria inhonorarent et audientibus Sinis in derisum et abominationem scenasque comoediales sacrosancta religionis christianae capita repraesentarent.

Aderat et alia quaepiam latens sermonis Latini invehendi in Sinas eiusque usus inibi radicandi causa, ex qua deliberatum fuit, ut potius erigeretur Macai seminarium, ad quod selecti e Sinis mitterentur adolescentes in literis Latinis et virtute christiana instituendi, ex quibus postea formarentur operarii, quam maturiores Sinae sacris ordinibus inaugurarentur cum tanto periculo contemptus rerum Divinarum.

\section{Patrum Sinensium pro usu linguae Sinicae in sacris rationes}

Verum Patribus qui vel Cantone vel Pekini degebant, profundiusque Sinicum penetrabant ingenium et ex ipsius Regiae moribus, velut e compendio totius imperii Sinici, quae alios latebant, caetera legebant, nihil minus tum curae fuit, quam ut vel Latino idiomate Divina peragerentur, vel iuventus Sinica aut Latinas literas edisceret aut Macaum mitteretur, vel demum expectaretur tempus quo illa literis et pietate instructa, iamque laboribus matura in [238r] campum prodiret. Stabat pro illis inviolatum hucusque, sed iniquitate temporum in usum non deductum, Pauli V Pontificis Maximi privilegium, quo, matura prius deliberatione cum sacro Purpuratorum Ecclesiae Patrum consilio facta, concessit sacerdotibus, qui ex Sinis futuri essent, ut in sua lingua non quidem vulgari, sed ea quae est literatorum in Sinis, Divina ministeria et officia celebrarent. Agnoverat nimirum illa providentia Sedis Apostolicae maiores et graviores sibi causas, huius privilegii dandi Sinensibus, toto terrarum orbe et seculorum lustris ab omni caeterarum gentium commercio divisis, suppetere, quam olim suis praedecessoribus, qui Maronitis, Armenis, Ethiopibus, Slavis 
aliisque nationibus, quibus olim Romani cum armis suum idioma invexerant, id ipsum benigne indulserant.

Palam est Sinas adeo linguae suae tenaces et literis addictos esse, ut quo illa remotior a commixtione caeterarum nationum, ideoque purior esset, istae vero in suo flore intaminatius conservarentur; eo feliciorem imperii sui futurum statum eiusdemque gubernatricem sapientiam characteribus suis, velut quibusdam munitionibus inclusam perennius imperaturam, arbitrentur. Hinc factum fuit postea, ut etiam ipsi dominatores Sinarum Tartari, quo magis ad ingenium et affectionem istam Sinensis populi sese accomodarent, lege et poena capitis caverunt, ne quis e Sinis idioma et literas Tartaricas addisceret, quantumvis natura ita comparatum sit, ut quisque, maxime vero victor et dominator exterarum gentium, ad gloriam suam suaeque nationis pertinere censeat non solum praeclare gestis, sed etiam idiomatis sui naturalis usu inclarescere.

\section{Linguam Latinam in Sinas introducere periculosum}

In hoc amore et pretio ab aliquot millibus annorum possessae et dominantis linguae, quis alienum obtrudet iis idioma, quibus par est contemptus exterorum ac nulla cum illis agendi, imo ne quidem illos cognoscendi cupido? Quis deturbata de suo solio, tot seculis adorata Regina in suo imperio, aliam ignotam in eo impune collocabit, eoque suis humeris illam sublimabit, ut sola ista caelestia et Divina loquatur, illa vero spectantibus suis adoratoribus ad pedes solii despecta iaceat?

Quodsi ad eos tantum addiscendae linguae Latinae studium referas, qui sacris initiandi aliorum saluti et Divinae legi promovendae operam sint navaturi, praeter ingentes impensas in utriusque linguae magistros, quas Sina non suppeditabit, duplex periculum timendum est: alterum religionis, alterum novae alicuius persecutionis. Constat Sinarum gentem aeque suspiciosissimam esse ac ingeniosissimam. Si usus in rebus Divinis Latinae linguae introducatur, quam soli discipuli europaeorum sacerdotum in- [238v] telligant, dubio procul affirmare liceat, orituras inde in iis politicis suspiciones occultarum aliquarum consultationum in perniciem reipublicae tendentium, quam molirentur Europaei.

Nam si inpraesentiarum, quando tam pauci sacerdotes et soli sacris altaribus assistunt linguaque Romana Divina illa mysteria exercent, evitari nequeunt gravissimae de ipsis conceptae imaginationes, ut vel hac sola ex causa omnes coetus et conventus christianorum, distributiones item sacrorum numismatum severo imperatoris interdicto subiectae sint, quantumvis publicis comitiis legis Divinae innocentia ab omni prorsus nota libera pronunciata fuerit, et imperatoris ipsius gratiae nullum tale crimen posse in Europaeos sacerdotes 
cadere demonstrent, quid futurum censendum erit, cum plures eiusdem extraneae linguae periti, eadem secum vel in solis Divinis officiis miscuerint sermones, cum imperatorem, a cuius nutu favor et inimicitiae mandarinorum totius imperii dependeat, tam benevolum rebus nostris non habuerimus? Ingens malum est suspicio! In ipsa pace et securitate, pericula et bella apprehendit, inter innocentes amicitias et consuetudines, nescio quid timet criminis, quod non nisi sanguine, vita, famae bonorumque iactura ulciscatur!

Iam vero quid timendum puritati religionis christianae ab illis acutissimis et sciendi novarum rerum cupidissimis Sinarum ingeniis, si exculta Latinis literis fuerint, nemo non videt. Coepisse iam aliqua Hollandorum in Sina commercia, non defutura aliorum; posse invehi libros non solum in diversis scientiis conscriptos, sed etiam pravis dogmatibus, mendaciis, calumniis, bellis inter principes christianos, schismatibus, aliisque monstris, in opprobrium integerrimae catholicae fidei refertos. Haec universa hucusque novellae isti christianitati ita sunt ignota, ut existiment omnes christianos per totum orbem diffusos, unius esse labii, moris, animi et in rebus fidei consensus amoreque inter se coniunctissimae voluntatis. Quae si ex lectione librorum latino idiomate evulgatorum alia inventa fuerint, quae in curiosa gente scandala, quis sensus de orthodoxa fide, quae morum corruptela, quae impedimenta alia legis Divinae amplectendae vel promovendae sint inde secutura, utinam exempla non docerent eorum, qui cum Macai in emporio tot nationum aliquamdiu morati essent, licet inibi nihil nisi catholicum videant, tamen ex visis paucorum, ut est humanae naturae fragilitas, pravis nonnullis moribus, ea reduces ad suos reportent, quae non nisi longo temporis cursu et medicina sanari possunt.

Atque haec quidem aliaque permulta quae alibi leguntur, de usu linguae Latinae non invehendo in Sinas, qui penitius Sinas inspiciebant. Caeterum latens, ut prius diximus, suberat causa, nescio an non [239r] commodis Europaeis immixta, quae eo demum conatuum impulit illos, qui linguae Latinae regnum in isto imperio fundare et stabilire desiderabant, ut missis Romam adversis informationibus, omnes postea curas oratorum e Sina ablegatorum eorumque rationes pro linga Sinica in sacris adhibenda, cum magno celerioris conversionis ad fidem illius imperii praeiudicio, inanes reddiderint.

\section{Iuvenes Sinae non possunt haberi aeque facile ac putatur}

Porro quod iuventutem Sinicam literis et pietate Macai instituendam, formandosque ex ea ad christianam culturam operarios attineret, censebant illi Patres sera illa esse nimirum auxilia et statum rei christianae in eo loco consistere, qui cum nihil securitatis inter medios imperatoris favores promitteret, invidiae autem aemulorum, iisdem gratiis regiis, quibus Nostri fruebantur, cre- 
scerent, et ea ipsa cunctatio quam Socii Pekini in lege Divina in pristinum statum asserenda experiebantur, nescio quid tempestatis minitaretur. Veteranorum in fide solida virtute et ardenti zelo, tot vicissitudinibus temporum obfirmato indigebat, non tyronibus, quorum plerumque, quantumvis magna videatur, virtus, plus spei, quam fructus ex se producit. Levia sunt iuventutis praesertim Sinicae ingenia, et nisi maturior aetas ea pondere suo appresserit, qua facilitate quidpiam melioris propositi arripiunt, eadem relinquunt. Et quamvis decursu temporis, accedente in eorum educatione magistrorum vigilantia et perfectioris vitae exemplis plurimum boni sperari possit, id tamen multorum annorum, non praesentis necessitatis opus est.

Adde facilius esse inter tot millia christianorum probatissima virtute et gradu literatorum insignes viros invenire, qui iam soluti matrimonio coelibem vitam cum laude christiana ducerent, quam selectos iuvenes nexibus coniugii non illigatos. Cum enim usu et more patriae a pueris pene a parentibus suis, vinculo coniugalibus innectantur, rarissimam avem parit Sina iuvenem sine uxore. Comparare autem pretio a parentibus filios, ut quidam censebant, eosque a teneris ad virtutem et scientiam operario in vinea Domini futuro necessariam instituere, et dispendiis ac litibus plenum negotium ob parentum inconstantiam, qui calumniis etiam impositis, suos, ubi adolevissent, filios per tribunalia requirerent, et christianae religioni dedecori futurum esset ob despectum Divinae legis, quam venditi et servi europaei, genti sui honoris et magnitudinis plane adoratrici, praedicarent. Felicioribus igitur temporibus [239v] reservandum esse delectum et institutionem iuventutis Sinicae, praesenti viris et viribus ad ministerium apostolicum factis utendum esse, cum aliae causae tum ipsa necessitas postulat.

His constitutis, aliis insuper postulatis additis, illa Patrum Sinensium congregatio Romam, ad Sedem Apostolicam et Praepositum Societatis Generalem Patrem Ioannem Paulum Oliva, electum oratorem suum Patrem Prosperum Intorcetta, natione Siculum, ablegavit. Cuius abitus ut lateret mandarinos Provinciae Quam Tum exulumque numerus adimpleretur, uti prius in locum Patris F[ratris?] Dominici Navarrete Pater Philippus Grimaldi, ita in locum Patris Prosperi Macao evocatus est Pater Emmanuel de Sequeira, natione Sina, olim adolescens in Europam et Curiam Romanam missus, post absoluta philosophiae et theologiae studia redux Macaum et in Sinam. Quanquam probabilius est in locum Patris Prosperi clam subintrasse Patrem Germanum Macret, Gallum, aut Patrem Carolum de Rocia, Sabaudum, qui eodem anno obiit. Sequeira enim natione Sina, non poterat supplere locum Patris Europaei (Pater Intorcetta Romam Procurator missus, in eius locum successit Pater Emmanuel de Sequeira, potius Pater Germanus Macret, de quo dicit Pater Couplet in suo "Catalogo" quod anno 1664 Macao venit in Provinciam Fokien ibidemque 
anno 1676 obiit, ex quo coniicere licet eum quidem eo anno Macao venisse in Quamcheu ibique remansisse coepta persecutione ac deinde subintrasse in carcerem in locum alicuius et post concessum reditum Patribus ad ecclesias ivisse in Fokien. Quidquid sit incertum est qui in locum Patris Intorcetta successit).

\section{A B S TR A C T}

The Chinese Rites Controversy definitively shaped the history of Christianity in China. When some missionaries were exiled in Canton from 1666 to 1671, they sought to resolve their disagreement on whether certain Confucian rituals could be practiced by Chinese Christian converts but their differences ended up even more entrenched. In his unpublished history of the China mission covering the period from 1640 to 1700 , the Polish Jesuit Tomasz Ignacy Szpot Dunin (1644-1713) gives an account of the discussions held in Canton. His account not only reveals previously known materials but also offers new insights on the Controversy.

Key words: Chinese Rites Controversy; Jesuits; Canton

Slowa kluczowe: Chinese Rites Controversy; Jesuits; Canton

\section{BIBLIOGRAPHY}

Bontinck, François. La lutte autour de la liturgie chinoise aux XVIIe et XVIIIe siècles. Louvain: Nauwelaerts, 1962.

Bosmans, Henri. "Documents relatifs à la liturgie chinoise: le mémoire de François de Rougemont à Jean Paul Oliva." Acta Bollandiana 33 (1914): 273-293.

Brancati, Francesco. Ms. Responsio apologetica de Sinensium ritibus politicis, BVE, Fondo Gesuitico 1250/5, 1251/8, 1299 and 1498; BNF Bréquigny 20:1-153; Ajuda 49-IV-62.1633 \& 49VI-8.9337; De Sinensium ritibus politicis acta. Paris: Nicolas Pépie, 1700.

Couplet, Philippe. Ms. Breve relatione dello stato e qualità delle missione della Cina, ARSI Jap. Sin.131; Secondino Gatta, Il natural lume de Cinesi, Monumenta Serica Monograph Series XXXVII. Nettetal: Steyler Verlag, 1998.

Danieluk, Robert. "Konfesjonał i pióro: Tomasz Ignacy Szpot Dunin, polski historiograf jezuickiej misji w Chinach," in Iesuitae in Polonia - Poloni Iesuitae. Piśmiennictwo tacińskie czasów nowożytnych, ed. Jarosław Nowaszcuk. Szczecin: Volumina, 2017, pp. 75-108.

Filippucci, Francesco Saverio. Ms. Explicatio 37 textuum Sinicorum, BVE, Fondo Gesuitico 1383, n. 11, ff. 70-101.

Filippucci, Francesco Saverio. Tractatus Patris Francisci Filippucci de Ritibus Sinicis quem in suo Praeludio promittit, BVE Fondo Gesuitico 1248/3, 115r-302r.

Filippucci, Francesco Saverio. Praeludium ad plenam disquisitionem, BVE 1249/7; De Sinensium ritibus politicis acta. Paris: Nicolas Pépie, 1700.

Filippucci, Francesco Saverio. Sagitta retorta, BVE Fondo Gesuitico 1247/8, 223r-311r; 1247/9, $316 \mathrm{r}-424 \mathrm{v}$.

Gabiani, Giovanni-Domenico. Ms. De ritibus ecclesiae sinicae permissis apologetica dissertatio, Ajuda 49-IV-62.1682, ff. 651-667v. 
Gabiani, Giovanni-Domenico. Apologeticae dissertationis appendix, BNF Espagnol 409: 159-188; Dissertatio apologetica, scripta anno 1680, de sinensium ritibus politicis. Liège: G.H. Streel, 1700.

Gabiani, Giovanni-Domenico. Ms. Elenchus elucubrationum ad objectarum controversiarum elucidationem conducentium; in Henri Bernard-Maître, "Un dossier bibliographique de la fin du XVIIe siècle sur la question des termes chinois." Recherches de science religieuse 36 (1949): 33-79.

Golvers, Noël. Letters of a Peking Jesuit: The Correspondance of Ferdinand Verbiest (1623-1688). Leuven: Ferdinand Verbiest Institute, 2017.

Grelon. Litterae annuae, V. Prov. Sinensis, of the years 1669 and 1670, ARSI Jap.Sin.122: 326-363; copy Jap.Sin.120: 1-201.

Intorcetta, Prospero. Ms. Informazione, 24 March 1672, APF - SRC I (1623-1674), ff. 573-582; copy BVE Fondo Gesuitico 1257/14; François Bontinck, La lutte autour de la liturgie chinoise aux XVIIe et XVIIIe siècles. Louvain: Nauwelaerts, 1962, pp. 437-460.

Intorcetta, Prospero. Ms. Apologetica disputatio de Officiis et Ritibus, BVE Fondo Gesuitico 1249/10, ff. 639-690; ms. BNF 409: 193-209, 214-242; Testimonium de Cultu Sinensi, 1668. Paris: Pépie, 1700.

Ip, Ka Kei. The Canton Conference (1667-1668): its content and significance. Master thesis. Macao: Saint Joseph University, 2010.

Joson, Henri. Willaert, Léon. Correspondance de F. Verbiest. Bruxelles: Palais des Académies, 1938.

Le Faure, Jacques. Ms. Dissertatio theologico-historica de avita Sinorum pietate erga defunctos, BNF Bréquigny 19; BVE Fondo Gesuitico 1250/3; Vanves, Brotier 104, 25-38 and 105; De Sinensium ritibus politicis acta. Paris: Nicolas Pépie, 1700.

Lubelli, Andrea. Ms. Reposta à alguns pontos que escreve o Illustrissimo Navarrete; BNF Espagnol 409: 192-196.

Menegon, Eugenio. "European and Chinese Controversies over Rituals," in Socio-religious Models, Rituals, and the Performativity of Practice, ed. Bruno Boute and Thomas Smaberg. Leiden: Brill, 2013, pp. 193-222.

Meynard, Thierry. "Could Chinese vegetarians be baptized? The Canton Conference and Adrien Grelon's report of 1688." Archivum Historicum Societatis Iesu (AHSI) vol. 87, fasc. 173 (2018-I): 75-145.

Meynard, Thierry. The Jesuit Reading of Confucianism: The First Complete translation of the Lunyu (1687) published in the West. Boston: Brill, 2011.

Meynard, Thierry. The Confucius Sinarum Philosophus: The First Translation of the Confucian Classics. Rome: IHSI, 2010.

Navarrete, Domingo. Tratados historicos, politicos, ethicos y religiosos de la monarchia de China. Madrid, 1676; English translation: Awnsham Churchill, A Collection of Voyages and Travels, vol. 1, London, 1704.

Noël, François. Castner, Gaspard. Summarium Novorum Autenticorum Testimoniorum. Rome: 1703.

Rougemont, Letter, Canton, 1667, BVE, Fondo Gesuitico 1257/29; Henri Bosmans, "Documents relatifs à la liturgie chinoise: le mémoire de François de Rougemont à Jean Paul Oliva". Acta Bollandiana 33 (1914): 273-293.

Sarpetri, Domenico Maria. Tratado del R.P.F. Domingos Sarpetri sobre la sentencia del P. Longobardi; ARSI: Fondo Gesuitico I.2: ff. 1-24; BNF Espagnol 409: 106-115; De Sinensium ritibus politicis Acta. Paris: Nicolas Pépie, 1700.

Sarpetri, Domenico Maria. Testimonium de libro sinico P. Matthaei; Apologia pro decreto, Louvain, 1700; Défense des nouveaux Chrestiens et des Missionaires de la Chine, du Japon, et des Indes. Paris 1688. Apologia pro decreto. Louvain: 1700.

Sarpetri, Ms. Breve notitia de unos de los fundamentos; Ajuda 49-IV-62: 697-713v; Brevis explicatio rationum aliquarum, Canton, 31 October 1670; Apologia pro decreto S.D.N. Alexandri VII, Louvain: 1700.

Standaert, Nicolas. Chinese Voices in the Rites Controversy. Rome: IHSI, 2012. 
Szpot Dunin, Tomasz Ignacy. Letter to Tamburini, dated 23 January 1710; ARSI, Jap. Sin. 173, f. $22^{\text {rv }}$.

Szpot Dunin, Tomasz Ignacy. Collectanea historiae sinensis; ARSI, Jap. Sin. 104-105.

Verbiest, Ferdinand. Ms. Responsum apologeticum P. Ferdinandi Verbiest Societatis Jesu ad aliquot dubia, BVE Fondo Gesuitico 1257 /33; Archives Province de France, Brotier 104.

ThIERRY MeynaRD s.j. is currently professor and $\mathrm{PhD}$ director at the philosophy department of Sun Yat-Sen University, Guangzhou, where he teaches Western Philosophy and Latin Classics. He is the vice-director of the Archive for Introduction of Western Knowledge, at Sun Yat-Sen University. In 2012-2014, he was also the director of The Beijing Center for Chinese Studies, a study program established by the Jesuits in 1998, and he still supervises the research activity of this center. In 2003, he obtained his PhD in Philosophy from Peking University, presenting a thesis on Liang Shuming. From 2003 to 2006, he taught philosophy at Fordham University, New York. Since 2006, he is a member of the Macau Ricci Institute. He has authored twenty academic articles and a dozen of essays. 
